\title{
The Improvement of Synthetic Unit Hydrograph Performance by Adjusting Model Parameters for Flood Prediction
}

\author{
I Gede Tunas ${ }^{\# 1}$, Nadjadji Anwar ${ }^{\# 2}$ and Umboro Lasminto ${ }^{\# 3}$ \\ ${ }^{\# 1,2,3}$ Department of Civil Engineering, Institut Teknologi Sepuluh Nopember (ITS) Surabaya 60111, Indonesia \\ ${ }^{\# 1}$ Department of Civil Engineering, University of Tadulako, Palu 94118, Indonesia \\ 'tunasw@yahoo.com; ${ }^{2}$ nadjadji@gmail.com; ${ }^{3}$ umboro_hydro@yahoo.com
}

\begin{abstract}
One of the important factors in water resources management is the determination of design flood associated with determining the size, capacity and age of the water resources structures to be built. Determination of design flood can be done in various ways, one of which is very popular to date is discharge prediction using synthetic unit hydrograph (SUH) approach. The use of unit hydrograph models has been widely applied in various parts of the world, especially in Indonesia, some of which are Snyder, Nakayasu, GAMA I and ITB-1. These methods are considered to have a good performance because it has to accommodate the characteristics of watersheds in a model parameter that greatly contributed to the process of rainfall-runoff transformation. However, in some cases it also provides a sizeable deviation, especially in Indonesia, considering that watersheds in Indonesia have different characteristics with watersheds in the United States where Snyder Unit Hydrograph developed. To overcome these problems, the unit hydrograph performance must be improved so that it can be used in various watersheds to obtain the smallest deviations. This research was conducted in 8 watersheds located in Central Sulawesi Province, Indonesia. This study aimed to improve the performance of Snyder Unit Hydrograph Model, covering Snyder, Nakayasu, SCS, GAMA I, ABG and ITB-1. The improvement of model performance was conducted by adjusting model parameters, in this case using Solver Tool on Microsoft Excel. Evaluation was done by the error indicator such as coefficient of Nash-Sutcliffe model efficiency (E). The study result showed that model parameter adjustment could decrease a deviation of SUH model parameter for peak discharge and average peak time up to $30 \%$ and could increase NashSutcliffe Model Efficiency Coefficient (E) up to over $80 \%$. The decrease of a deviation of SUH model parameter and the increase of $E$ coefficient revealed that optimization using solver facility was effectively undertaken. However, not all deviations decreased but even increased significantly after optimization. It happened because the process of parameter optimization occurred simultaneously, and it was only based on a purpose function by maximizing Nash-Sutcliffe Model Efficiency Coefficient (E). The adjustment in this coefficient caused the increase or decrease of a parameter deviation of SUH Model depending on E value achieved on the optimization process. Overall, it could be declared that the decrease of a parameter deviation of SUH model was accompanied by the increase of Nash-Sutcliffe Model Efficiency Coefficient (E).
\end{abstract}

Keywords : performance improvement, synthetic unit hydrograph, model parameters, flood prediction

\section{INTRODUCTION}

One of the important factors in water resources management and planning was flood discharge estimation functioned to determine optimum discharge size associated with dimension and a life of structures. The aim of optimum flood discharge estimation was to plan structures which did not have over a dimension (over estimated) implying on the big cost of structures or too small dimension (under estimated) causing a bigger risk of structure failures.

One method that could be deployed to predict flood discharge was a hydrograph base. This method had been widely used either in overseas or in Indonesia as it was assumed to be able to imitate flood behavior from the beginning up to the end of the flood in a hydrograph format. Some of hydrograph bases particular a synthetic unit hydrograph commonly used in Indonesia, among others, were Snyder, Nakayasu, SCS, GAMA I, ABG and ITB-1. However, in some cases, these methods had obvious weaknesses because they could produce bigger deviation resulting in discharge size. Therefore, these method performances needed to be improved by adjusting their model parameters using optimization. Optimization was a procedure to maximize or minimize purpose function by changing a constraint function so that optimum value parameters could be determined.

This study became very important as on 8 observed watersheds as objects of the study did not have a guidance used for references how to predict flood with the best performance. The best way produced from the optimization process was expected to be references for flood prediction, particularly in Central Sulawesi Province - Indonesia. 


\section{MATERIALS AND METHODS}

This study used 8 observed watersheds in Central Sulawesi Province-Indonesia. They were Bahomoleo watershed, Pinamula watershed, Toaya watershed, Bangga watershed, Singkoyo watershed, Tambun watershed, Malino and Bunta watersheds, geographically scattered in 6 river basins in Central Sulawesi Province-Indonesia (Fig. 1 and Fig. 2). These watersheds were located in $119^{\circ} 53^{\prime} 32^{\prime \prime} \mathrm{E}-122^{\circ} 19^{\prime} 47^{\prime \prime} \mathrm{E}$ and $02^{\circ} 28^{\prime} 34^{\prime \prime} \mathrm{S}-01^{\circ} 09^{\prime} 48^{\prime \prime} \mathrm{N}$.

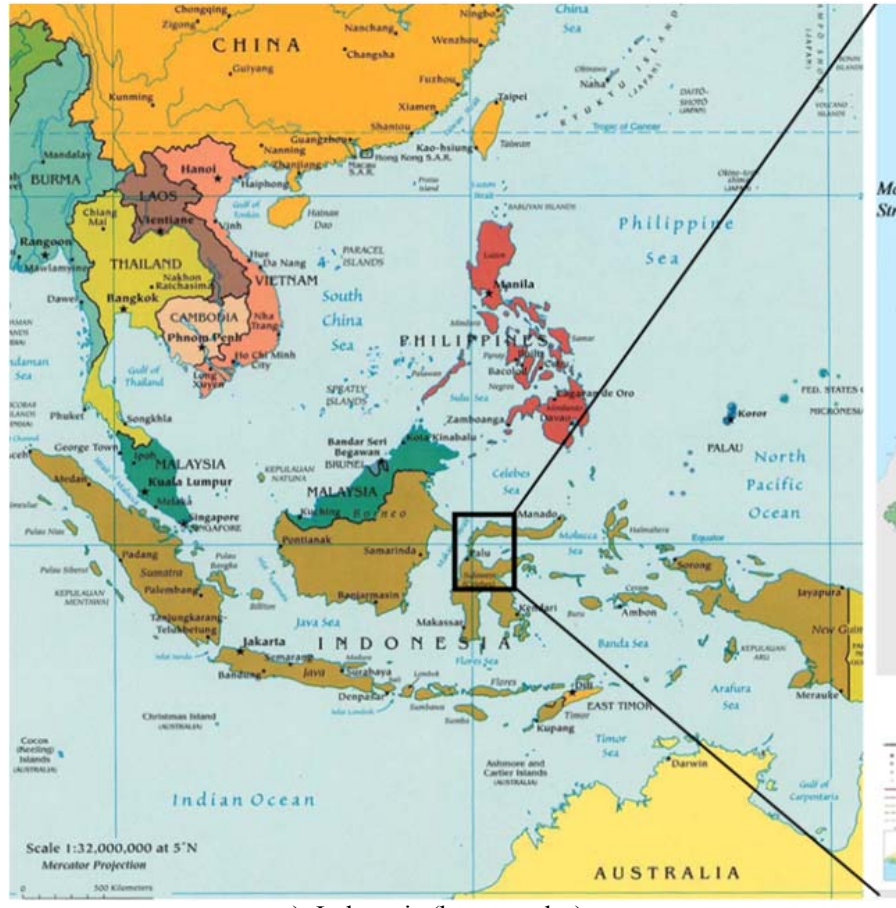

a). Indonesia (brown color)

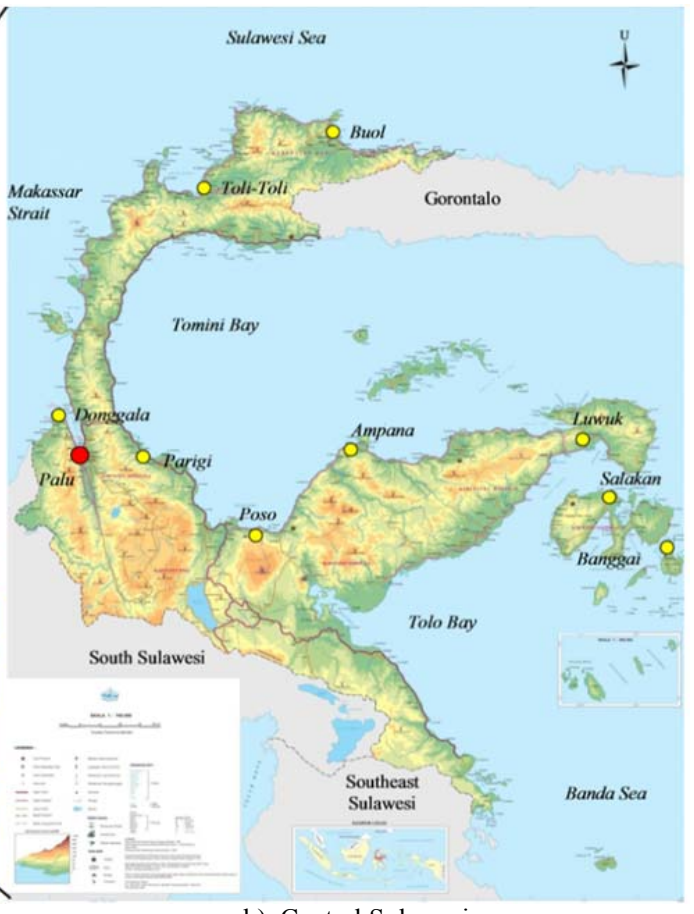

b). Central Sulawesi

Fig. 1. Location of research [1]
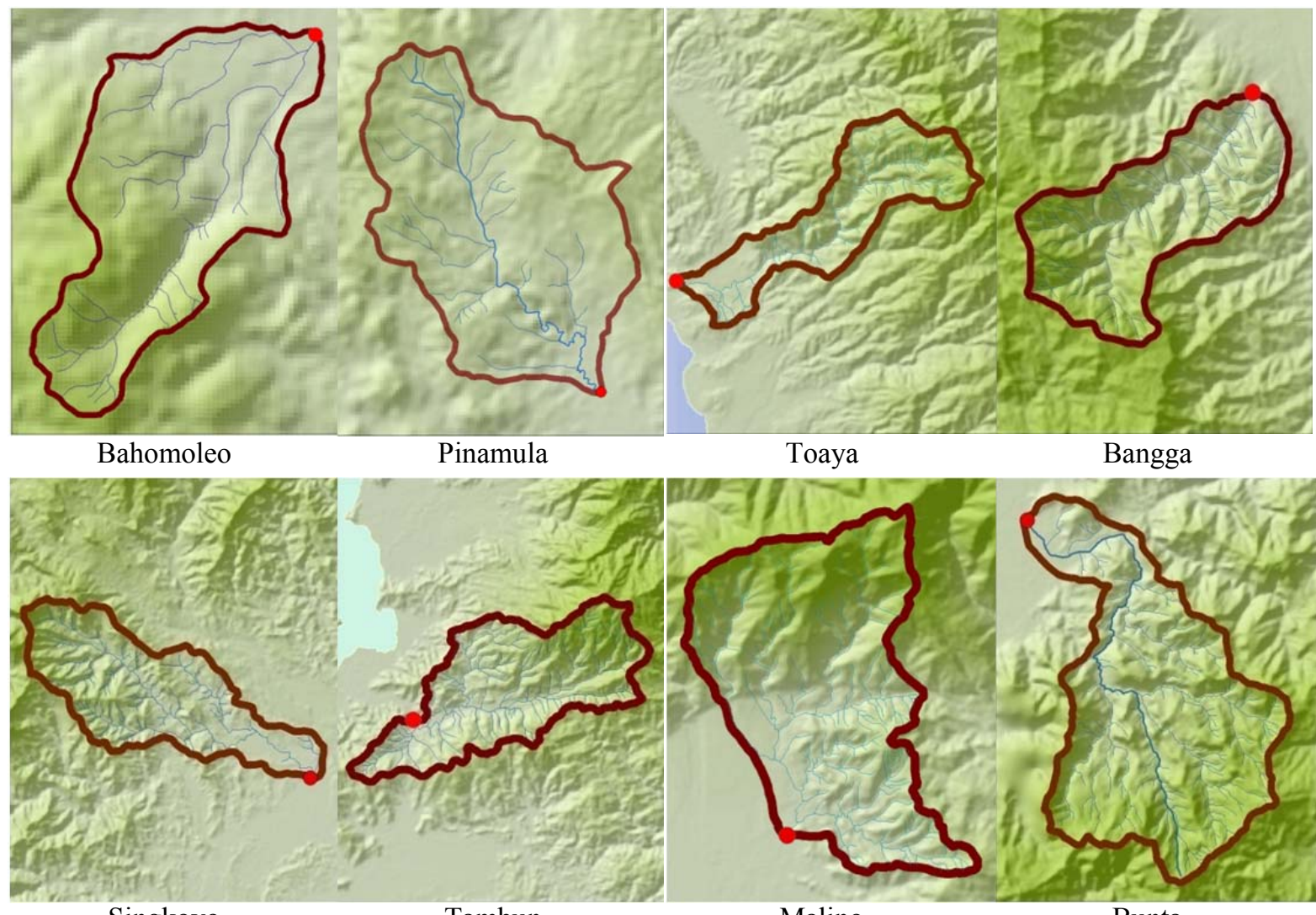

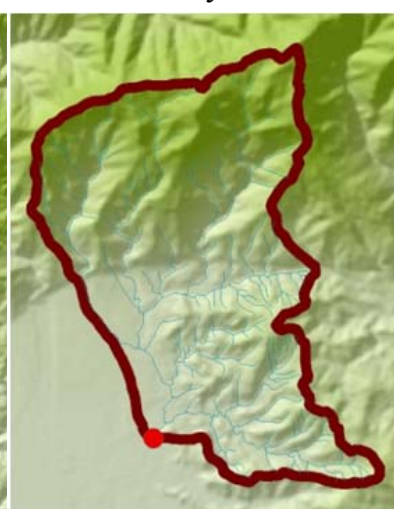

Malino
Bangga

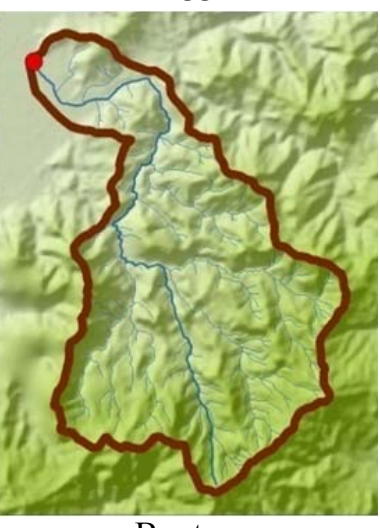

Bunta

Fig. 2.Eight (8) observed watersheds [1,2] 
The 8 observed watersheds as the research objects had an area of $23.88 \mathrm{~km}^{2}$ up to $144.73 \mathrm{~km}^{2}$ and all categorized as mesoscale watersheds with an area of $10<\mathrm{A}<1000 \mathrm{~km}^{2}[3,4]$. These watersheds had various format factors (FB). The highest watershed format factor was Tambun watershed with 0.50 reflecting watershed format similarity with format factor of 0.754 for a complete circle [5].In details, the morphometry characteristics of 8 observed watersheds are presented in Table I.

TABLE I. Morphometry parameters of 8 watersheds.

\begin{tabular}{|c|c|c|c|c|c|c|c|c|c|}
\hline \multirow{2}{*}{ No } & \multirow{2}{*}{ Parameters } & \multicolumn{8}{|c|}{ Watersheds } \\
\hline & & Bahomoleo & Pinamula & Toaya & Bangga & Singkoyo & Tambun & Malino & Bunta \\
\hline 1 & $\begin{array}{l}\text { Watershed area }(A, \\
\left.\mathrm{km}^{2}\right)\end{array}$ & 23.88 & 49.35 & 65.51 & 68.19 & 116.05 & 118.19 & 128.75 & 144.73 \\
\hline 2 & $\begin{array}{l}\text { Main river length }(L \text {, } \\
\mathrm{km})\end{array}$ & 10.32 & 15.64 & 21.82 & 16.48 & 26.81 & 19.99 & 19.19 & 28.7 \\
\hline 3 & Main river slope $(S)$ & 0.0763 & 0.0342 & 0.0653 & 0.08948 & 0.0456 & 0.0975 & 0.1081 & 0.0635 \\
\hline 4 & $\begin{array}{l}\text { Main river length } \\
\text { from centroid of } \\
\text { watershed to outlet } \\
\left(L_{c}, \mathrm{~km}\right)\end{array}$ & 6.11 & 6.07 & 9.3 & 7.65 & 10.16 & 10.94 & 9.22 & 8.83 \\
\hline 5 & $\begin{array}{l}\text { Shape factor of } \\
\text { watershed }(F B)\end{array}$ & 0.30 & 0.39 & 0.21 & 0.37 & 0.22 & 0.50 & 0.49 & 0.36 \\
\hline 6 & Number of order $(n)$ & 4 & 3 & 4 & 4 & 4 & 5 & 5 & 5 \\
\hline 7 & Number of joint $(J N)$ & 32 & 32 & 65 & 81 & 105 & 113 & 124 & 168 \\
\hline 8 & $\begin{array}{l}\text { River length of first } \\
\text { order }(\mathrm{km})\end{array}$ & 20.18 & 36.85 & $\begin{array}{r}48.9 \\
6 \\
\end{array}$ & 68.90 & 76.86 & 122.93 & 118.69 & 113.15 \\
\hline 9 & $\begin{array}{l}\text { River length of } \\
\text { whole order }(\mathrm{km})\end{array}$ & 43.06 & 61.36 & $\begin{array}{r}88.9 \\
4\end{array}$ & 116.96 & 144.69 & 199.39 & 205.68 & 222.60 \\
\hline 10 & Drainage density $(D)$ & 1.80 & 1.24 & 1.36 & 1.72 & 1.25 & 1.69 & 1.60 & 1.54 \\
\hline 11 & $\begin{array}{l}\text { Reach number of } \\
\text { first order }\end{array}$ & 34 & 34 & 67 & 92 & 106 & 125 & 137 & 182 \\
\hline 12 & $\begin{array}{l}\text { Reach number of } \\
\text { whole order }\end{array}$ & 70 & 71 & 137 & 180 & 211 & 242 & 267 & 356 \\
\hline 13 & Curve Number (CN) & 66 & 66 & 66 & 66 & 66 & 66 & 66 & 66 \\
\hline
\end{tabular}

Other data used in this study were rainfall data set and flood hydrograph on a certain occasion. These data were obtained from government or private institutions which had data such as River Basin Agency, Watershed Management Bureau, Meteorological, Climatological and Geophysical Agency, Provincial Government Offices (Public Works, Agriculture, Forestry) with a range of data from 2009-2014. Then, all collected data were chosen and selected with a certain requirement and they were verified with rainfall data and AWLR data. These chosen and selected date were data used as the samples for this study.

This study was undertaken by decreasing average unit hydrograph represented each watershed. The decrease of unit hydrograph was carried out by separating runoff hydrograph directly to respective flood cases with basic flow using one method as a straight line method. The runoff volume was directly computed based on effective rainfall. The unit hydrograph ordinate was obtained by dividing directly runoff hydrograph ordinate with its effective high rainfall. The analysis of unit hydrograph parameter was carried out to average unit hydrograph by taking an average of peak discharge (QP), peak time (TP), and base time (TB). Then, they were used as standards to determine an average standard of unit hydrograph ordinate.

The next step was to conclude synthetic unit hydrograph of each SUH model including Snyder, Nakayasu, SCS, GAMA I, ABG and ITB-1. The equations used are as follows:

1) Snyder [6]

$$
\begin{aligned}
& Q P=0.278\left(\frac{C_{p}}{T L}\right) A \\
& T_{l}=C_{t}\left(L L_{c}\right)^{\mathrm{n}} \\
& T P=T L+\frac{T R}{2} \\
& T B \approx 5 T L
\end{aligned}
$$


$\mathrm{QP}=$ peak discharge $\left(\mathrm{m}^{3} / \mathrm{s}\right), \mathrm{A}=$ watershed area $\left(\mathrm{km}^{2}\right), \mathrm{TL}=$ time lag (hour), $\mathrm{C}_{\mathrm{t}}=$ Storage coefficient (1.4-1.7), $\mathrm{L}=$ main river length $(\mathrm{km}), \mathrm{L}_{\mathrm{c}}=$ main river length from centroid of watershed to outlet, $\mathrm{C}_{\mathrm{p}}=$ empirical constants $(0.15-0.19)$ and $\mathrm{TB}=$ base time.

2) Nakayasu [7]

$Q P=\frac{A R 0}{3.6(0.3 T P+\alpha T g)}$

$T P=T g+0.8 \mathrm{Tr}$

$\mathrm{QP}=$ peak discharge $\left(\mathrm{m}^{3} / \mathrm{s}\right), \mathrm{A}=$ watershed area $\left(\mathrm{km}^{2}\right), \mathrm{R} 0=$ unit rainfall $(\mathrm{mm}), \mathrm{TP}=$ peak time (hour), $\alpha=$ runoff coefficient, $\mathrm{Tg}=$ time of concentration (hour) and $\mathrm{Tr}=$ rainfall duration $(\mathrm{mm})$

3) SCS [8]

$Q P=\frac{A R 0}{3.6 T P}$

$T P=T L+0.5 T r$

$T B \approx 5 T P$

$\mathrm{QP}=$ peak discharge $\left(\mathrm{m}^{3} / \mathrm{s}\right), \mathrm{A}=$ watershed area DAS $\left(\mathrm{km}^{2}\right), \mathrm{R} 0=$ unit rainfall $(\mathrm{mm}), \mathrm{TL}=$ time lag (hour), $\mathrm{TP}=$ peak time (hour) and $\mathrm{Tr}=$ rainfall duration $(\mathrm{mm})$

4) GAMA I [9]

$$
\begin{aligned}
& Q P=0.1836 A^{0.5886} J N^{0.2381} T R^{-0.4008} \\
& T R=0.43\left(\frac{L}{100 S F}\right)^{3}+1.0665 S I M+1.2775 \\
& T B=27.4132 T R^{0.1457} S^{-0.0986} S N^{0.7344} R U A^{0.2574}
\end{aligned}
$$

$\mathrm{QP}=$ peak discharge $\left(\mathrm{m}^{3} / \mathrm{s}\right), \mathrm{L}=$ main river length $(\mathrm{km}), \mathrm{SIM}=$ symmetry factor, $\mathrm{JN}=$ number of joint, $\mathrm{TR}=$ rising time (hour), $\mathrm{TB}=$ base time (hour), $\mathrm{S}=$ main river slope, $\mathrm{SN}=$ frequency number, $\mathrm{RUA}=$ upstream watershed area factor and $\mathrm{A}=$ watershed area $\left(\mathrm{km}^{2}\right)$.

5) ABG [10]

$$
\begin{aligned}
& q(t)=\left(\frac{T}{T P}\right)^{\alpha} \exp \left[\frac{2}{\gamma}\left\{1-\left(\frac{T}{T P}\right)\right\}^{\beta}\right] \\
& Q P=8.39737\left(\frac{A}{L}\right)^{2.42256} W F^{-0.55581} S^{\prime} I M^{1.26217} J N^{-0.66405} \\
& T P=0.06003 L+4.1619 S I M+19.1415 S F-12.6165 \\
& T B=3.45351 A^{-0.20651} L^{0.7277} S^{-0.14111}
\end{aligned}
$$

$\mathrm{q}(\mathrm{t})=$ unit discharge $\left(\mathrm{m}^{3} / \mathrm{s}\right), \alpha, \beta, \gamma=$ shape factor of hydrograph, $\mathrm{L}=$ main river length $(\mathrm{km})$, SIM=symmetry factor, $\mathrm{SF}=$ source factor, $\mathrm{JN}=$ number of joint, $\mathrm{WF}=$ width factor, $\mathrm{TR}=$ rising time (hour), $\mathrm{TB}=$ base time (hour), $\mathrm{S}=$ main river slope and $\mathrm{A}=$ watershed area $\left(\mathrm{km}^{2}\right)$.

6) ITB-1 [11]

$$
\begin{aligned}
& q(t)=\exp \left\{2-\left(\frac{T}{T P}\right)-\frac{1}{\left(\frac{T}{T P}\right)}\right\}^{\alpha C_{p}} \\
& Q P=\frac{1}{3.6 T P} \frac{A}{A_{S U H}} \\
& T P=C t 0.81225 L^{0.6} \\
& T B \approx 10 T P
\end{aligned}
$$

$\mathrm{q}(\mathrm{t})=$ unit discharge $\left(\mathrm{m}^{3} / \mathrm{s}\right), \mathrm{QP}=$ peak discharge $\left(\mathrm{m}^{3} / \mathrm{s}\right), \mathrm{A}_{\mathrm{SUH}}=$ area under hydrograph curve, $\alpha, \mathrm{C}_{\mathrm{p}}=$ shape parameter of hydrograph, $\mathrm{C}_{\mathrm{t}}=$ time coefficient, $\mathrm{L}=$ main river length $(\mathrm{km}), \mathrm{TP}=$ peak time (hour), $\mathrm{TB}=$ base time (hour).

The final step was a performance test of SUH model. SUH model was evaluated based on performance analysis. This model performance analysis was conducted to recognize the model success in representing river discharge which was evaluated with comparison test between measurement discharge with simulation discharge using Nash-Sutcliffe Model Efficiency Coefficient (E) [12] as follows: 


$$
E=1-\frac{\sum_{i=1}^{n}\left(Q_{\text {sim }_{i}}-Q_{o b s_{i}}\right)^{2}}{\sum_{i=1}^{n}\left(Q_{\text {sim }_{i}}-\overline{Q_{o b s_{l}}}\right)^{2}}
$$

The value of error indicator was between $\infty$ and 1 . The lower error indicator value, the lower performance of model produced was, and on the other hand when the indicator value raised close to 1 , the model performance got higher. In general, model performance was assumed to be good if the maximum value of maximum error indicator was $10 \%$ [13]. In addition, the deviation of peak time (TP), peak discharge (QP), and base time (TB) were also evaluated.

$$
\begin{gathered}
P_{Q P}=\frac{Q P_{\text {sim }}-Q P_{o b s}}{Q P_{o b s}} \\
P_{T P}=\frac{T P_{\text {sim }}-T P_{o b s}}{T P_{o b s}} \\
P_{T B}=\frac{T B_{\text {sim }}-T B_{o b s}}{T B_{o b s}}
\end{gathered}
$$

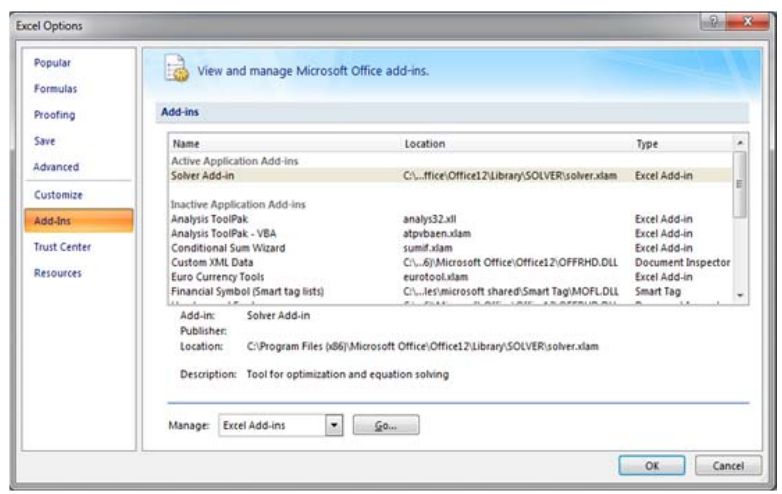

a) Excel Option

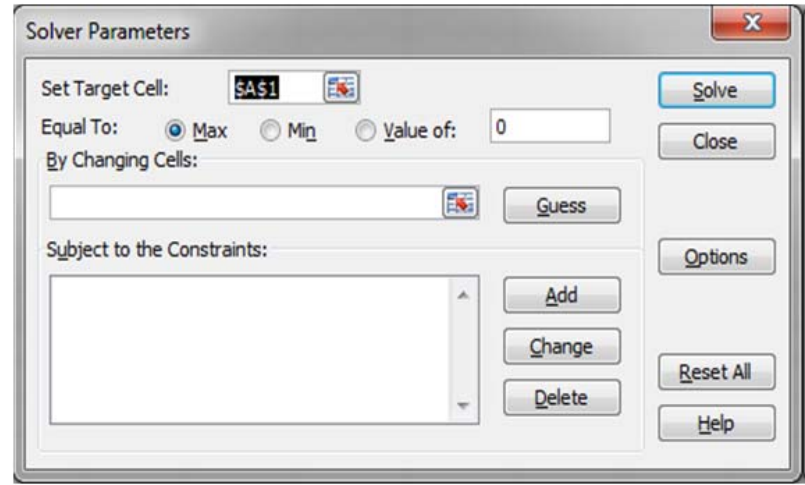

b) Solver Parameters

Fig.3. Activation of solver facility on Microsoft Excel

The purpose of the aforementioned increase of SUH model performance was to decrease the parameter deviation of peak discharge, peak time, and base time of hydrograph, and to increase Nash-Sutcliffe Model Efficiency Coefficient (E). However, not all SUH models could be decreased their parameter deviations, particularly SUH model of which hydrograph parameter was set based on the equation. The performance improvement of SUH model was accomplished by adjusting coefficient using Solver facility on Microsoft Excel. The Solver facility could be activated via Menu Excel Option as in Fig. 3.

Basically, a solver is one of the facilities provided by Microsoft Excel to complete computation which requires optimization (calibration) of some parameters based on fixed limit condition. An optimized parameter is set up based on constraint as required by each model. Optimization is based on purpose function and its function value can be minimized and maximized or is based on a certain value. Solver ability in optimization can be adjusted by changing the limits of iteration, precision, tolerance, convergence, and applied assumption.

\section{RESULTS AND DISCUSSION}

A measured unit hydrograph of the respective watershed was decreased from 75 rainfall data sets and flood hydrograph by separating base stream based on effective rainfall by computing the number of phi index $(\phi)$. The separation of base stream used a straight-line method with an assumption that base stream increased by time. This separation technique of base stream had been widely used by hydrology researchers such as Sri Harto [9], Limantara [14], and others with various arguments such as an easy way to identify the end of the base stream on a hydrograph recession side. Bearing in mind that the analysis was only resulted in 3 average unit hydrograph parameters i.e. QP, TP and TB. Therefore to get their hydrograph curves, retrial by controlling runoff volume divided directly by watershed $=1 \mathrm{~mm}$ could be used. The parameters of average unit hydrograph for respective watersheds observed is seen in Table II, where hydrograph peak time is around 1.35 to 3.32 hours, hydrograph peak flow is around 1.58 to $4.98 \mathrm{~m}^{3} / \mathrm{sec}$ and hydrograph base time is about 12 to 28 hours. 
TABLE II. Parameters of average unit hydrograph at 8 watersheds.

\begin{tabular}{|c|l|c|c|c|}
\hline \multirow{2}{*}{ No. } & \multirow{2}{*}{ Watersheds } & \multicolumn{3}{|c|}{ Parameters of average unit hydrograph } \\
\cline { 3 - 5 } & & $\mathrm{TP}($ hour$)$ & $\mathrm{QP}\left(\mathrm{m}^{3} / \mathrm{s}\right)$ & TB (hour) \\
\hline 1 & Bahomoleo & 1.35 & 1.58 & 12.00 \\
\hline 2 & Pinamula & 2.10 & 2.49 & 16.00 \\
\hline 3 & Toaya & 2.68 & 2.79 & 18.00 \\
\hline 4 & Bangga & 2.18 & 3.17 & 16.00 \\
\hline 5 & Singkoyo & 3.15 & 4.09 & 26.00 \\
\hline 6 & Tambun & 2.51 & 4.59 & 24.00 \\
\hline 7 & Malino & 2.44 & 4.98 & 24.00 \\
\hline 8 & Bunta & 3.32 & 4.77 & 28.00 \\
\hline
\end{tabular}

The aforementioned 6 SUH models were Snyder, Nakayasu, SCS, GAMA I, ABG, and ITB-1. They were optimized based on purpose function by maximizing Nash-Sutcliffe Model Efficiency Coefficient (E) which was equal with 1, with the types and the number of optimization parameters relying upon evaluated SUH model as shown in Table III. SUH model parameters which had been determined as optimization parameters were parameters which were able to be calibrated or adjusted to maximize each model performance.

TABLE III. Optimization parameters of 6 Models

\begin{tabular}{|c|l|l|}
\hline No. & Models & \multicolumn{1}{c|}{ Optimization parameters } \\
\hline 1 & Snyder & Storage coefficient $\left(\mathrm{C}_{\mathrm{t}}\right)$, empirical constants $\left(\mathrm{C}_{\mathrm{p}}\right)$ and constants $(\mathrm{n})$ \\
\hline 2 & Nakayasu & Runoff coefficient $(\alpha)$ \\
\hline 3 & SCS & Curve Number $(\mathrm{CN})$ \\
\hline 4 & GAMA I & Storage coefficient of watershed $(\mathrm{K})$ \\
\hline 5 & ABG & Parametersof $\alpha, \beta$ and $\gamma$ \\
\hline 6 & ITB-1 & $\begin{array}{l}\text { Time coefficient }\left(\mathrm{C}_{\mathrm{t}}\right), \text { peak discharge coefficient }\left(\mathrm{C}_{\mathrm{p}}\right) \text { and } \\
\text { coefficient of } \alpha\end{array}$ \\
\hline
\end{tabular}

A hydrograph curve of respective SUH model before and after parameter optimization is presented in Fig. 4 , and the parameter optimization result of 6 SUH models with a control of Nash-Sutcliffe Model Efficiency Coefficient (E) is presented in Table IV and Table V. Based on the optimization result, it revealed that 2 model parameters which did not change were $C_{t}$ parameter on Snyder SUH with the value of 0.8 and $\alpha$ parameter on ABG SUH with the value of 2 . This meant that optimum condition that had been reached by the two parameters took place before optimization was undertaken. These two parameters played role to control hydrograph format. It differed with others, these two parameters changed with various values in a quite bigger range depending on the best performance (purpose function) attained in the optimization process. This phenomenon disclosed that these parameters had high sensitivities so that they play important roles to determine their model performances. Therefore, conscientiousness and sensitivities to conclude the value of parameters were badly required.

TABLE IV. Coefficients and parameters adjustment of Snyder, Nakayasu, SCS and GAMA I

\begin{tabular}{|c|c|c|c|c|c|c|c|c|}
\hline \multirow{3}{*}{ No } & \multirow{3}{*}{\multicolumn{2}{|c|}{ Watersheds }} & \multicolumn{6}{|c|}{ Synthetic Unit Hydrograph } \\
\hline & & & \multicolumn{3}{|c|}{ Snyder } & \multirow{2}{*}{$\begin{array}{c}\text { Nakayasu } \\
\alpha \alpha\end{array}$} & \multirow{2}{*}{$\frac{\mathrm{SCS}}{\mathrm{CN}}$} & \multirow{2}{*}{$\frac{\text { GAMA I }}{\mathrm{K}}$} \\
\hline & & & $\mathrm{C}_{\mathrm{t}}$ & $\mathrm{C}_{\mathrm{p}}$ & $\mathrm{n}$ & & & \\
\hline \multirow[t]{2}{*}{1} & \multirow[t]{2}{*}{ Bahomoleo } & Before & 0.8 & 1.2 & 0.2 & 0.8 & 2.3 & 79.0 \\
\hline & & After & 0.8 & 1.3 & 0.0 & 1.4 & 1.4 & 76.2 \\
\hline \multirow[t]{2}{*}{2} & \multirow[t]{2}{*}{ Pinamula } & Before & 0.8 & 1.2 & 0.2 & 1.4 & 3.0 & 81.0 \\
\hline & & After & 0.8 & 1.5 & 0.1 & 2.3 & 2.1 & 78.2 \\
\hline \multirow[t]{2}{*}{3} & \multirow[t]{2}{*}{ Toaya } & Before & 0.8 & 1.2 & 0.2 & 1.7 & 3.3 & 81.9 \\
\hline & & After & 0.8 & 1.7 & 0.2 & 2.4 & 3.0 & 80.9 \\
\hline \multirow[t]{2}{*}{4} & \multirow[t]{2}{*}{ Bangga } & Before & 0.8 & 1.2 & 0.2 & 1.8 & 3.1 & 81.3 \\
\hline & & After & 0.8 & 1.5 & 0.2 & 2.8 & 2.3 & 78.9 \\
\hline \multirow[t]{2}{*}{5} & \multirow[t]{2}{*}{ Singkoyo } & Before & 0.8 & 1.2 & 0.2 & 2.8 & 3.5 & 82.4 \\
\hline & & After & 0.8 & 1.5 & 0.2 & 3.7 & 3.2 & 81.5 \\
\hline 6 & Tambun & Before & 0.8 & 1.2 & 0.2 & 3.0 & 3.3 & 82.0 \\
\hline
\end{tabular}




\begin{tabular}{|c|c|c|c|c|c|c|c|c|}
\hline \multirow{4}{*}{ No } & \multirow{3}{*}{\multicolumn{2}{|c|}{ Watersheds }} & \multicolumn{6}{|c|}{ Synthetic Unit Hydrograph } \\
\hline & & & \multicolumn{3}{|c|}{ Snyder } & \multirow{3}{*}{$\begin{array}{c}\text { Nakayasu } \\
\alpha \\
4.1\end{array}$} & \multirow{3}{*}{$\begin{array}{l}\text { SCS } \\
\text { CN } \\
2.7\end{array}$} & \multirow{3}{*}{$\begin{array}{c}\text { GAMA I } \\
\mathrm{K} \\
80.0\end{array}$} \\
\hline & & & $\mathrm{C}_{\mathrm{t}}$ & $\mathrm{C}_{\mathrm{p}}$ & $\mathrm{n}$ & & & \\
\hline & & After & 0.8 & 1.4 & 0.2 & & & \\
\hline \multirow[t]{2}{*}{7} & \multirow{2}{*}{ Malino } & Before & 0.8 & 1.2 & 0.2 & 3.3 & 3.3 & 81.8 \\
\hline & & After & 0.8 & 1.3 & 0.2 & 4.5 & 2.5 & 79.4 \\
\hline \multirow[t]{2}{*}{8} & \multirow{2}{*}{ Bunta } & Before & 0.8 & 1.2 & 0.2 & 3.6 & 3.4 & 82.3 \\
\hline & & After & 0.8 & 1.4 & 0.2 & 4.3 & 3.1 & 81.4 \\
\hline
\end{tabular}

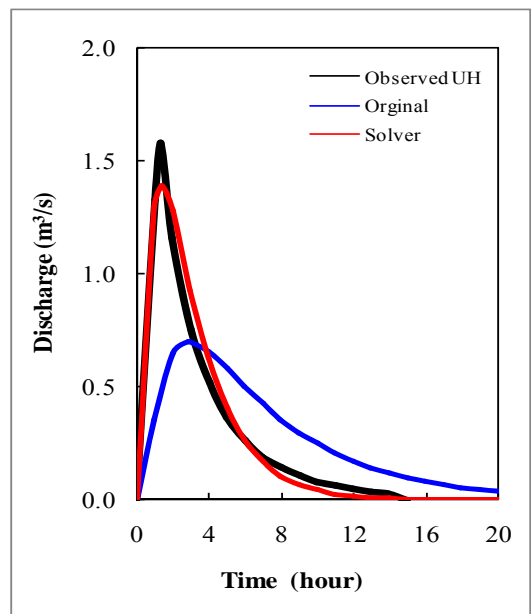

a) Snyder

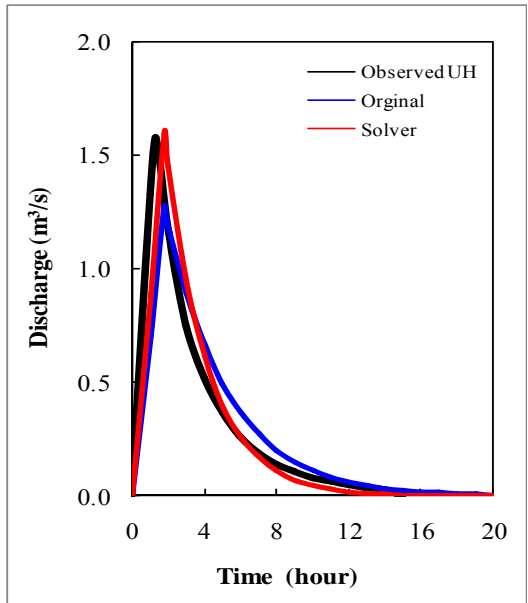

d) GAMA I

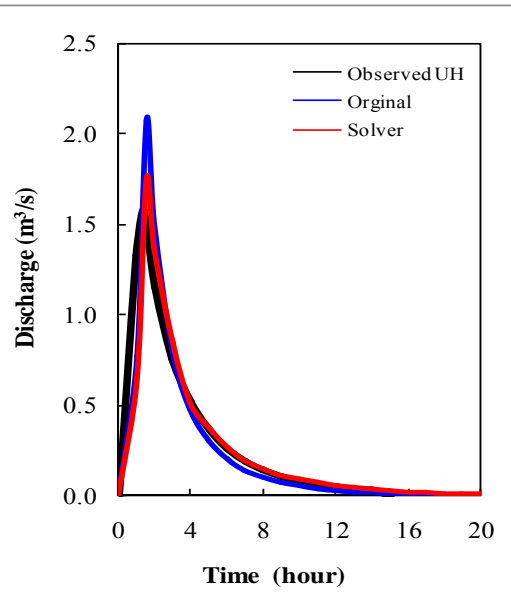

b) Nakayasu

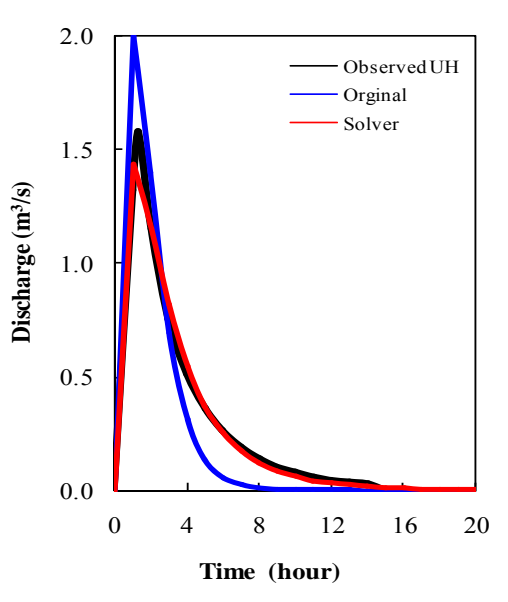

e) $\mathrm{ABG}$

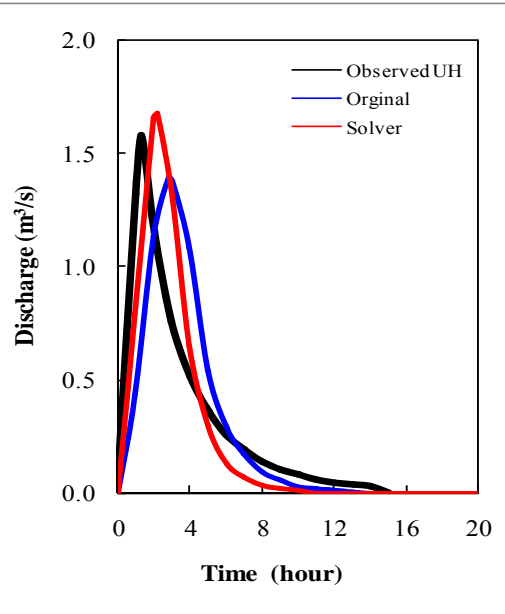

c) SCS

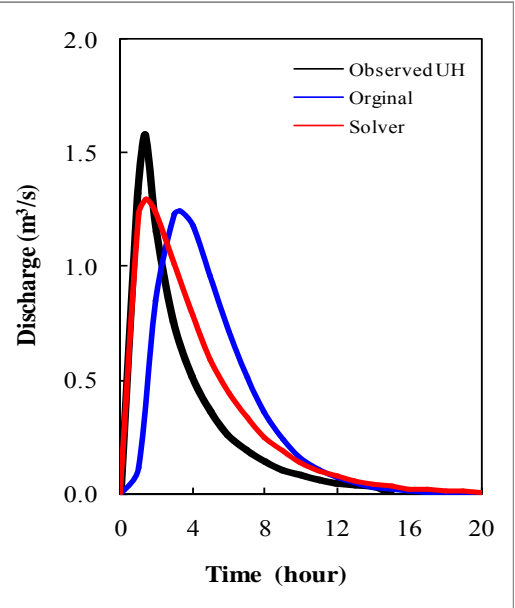

f) ITB-1

Fig.4. The changes of 6 curves after parameters optimization at Bahomoleo Watershed.

TABLE V. Coefficients and parameters adjustment of ABG and ITB-1

\begin{tabular}{|c|c|c|c|c|c|c|c|c|}
\hline \multirow{3}{*}{ No } & \multirow{3}{*}{\multicolumn{2}{|c|}{ Watersheds }} & \multicolumn{6}{|c|}{ Synthetic Unit Hydrograph } \\
\hline & & & \multicolumn{3}{|c|}{$\mathrm{ABG}$} & \multicolumn{3}{|c|}{ ITB-1 } \\
\hline & & & $\alpha$ & $\beta$ & $\gamma$ & $\mathrm{C}_{\mathrm{t}}$ & $\mathrm{C}_{\mathrm{p}}$ & $\alpha$ \\
\hline \multirow[t]{2}{*}{1} & \multirow[t]{2}{*}{ Bahomoleo } & Before & 2.00 & 0.73 & 0.74 & 1.00 & 1.50 & 1.00 \\
\hline & & After & 2.00 & 0.44 & 0.44 & 0.43 & 0.66 & 0.66 \\
\hline \multirow[t]{2}{*}{2} & \multirow[t]{2}{*}{ Pinamula } & Before & 2.00 & 0.86 & 0.86 & 1.00 & 1.50 & 1.00 \\
\hline & & After & 2.00 & 0.46 & 0.46 & 0.53 & 1.19 & 0.52 \\
\hline \multirow[t]{2}{*}{3} & Toaya & Before & 2.00 & 1.96 & 1.96 & 1.00 & 1.50 & 1.00 \\
\hline & & After & 2.00 & 1.00 & 1.00 & 0.53 & 1.24 & 0.61 \\
\hline
\end{tabular}




\begin{tabular}{|c|c|c|c|c|c|c|c|c|}
\hline \multirow{3}{*}{ No } & \multirow{3}{*}{\multicolumn{2}{|c|}{ Watersheds }} & \multicolumn{6}{|c|}{ Synthetic Unit Hydrograph } \\
\hline & & & \multicolumn{3}{|c|}{$\mathrm{ABG}$} & \multicolumn{3}{|c|}{ ITB-1 } \\
\hline & & & $\alpha$ & $\beta$ & $\gamma$ & $\mathrm{C}_{\mathrm{t}}$ & $\mathrm{C}_{\mathrm{p}}$ & $\alpha$ \\
\hline \multirow[t]{2}{*}{4} & \multirow[t]{2}{*}{ Bangga } & Before & 2.00 & 1.14 & 1.14 & 1.00 & 1.50 & 1.00 \\
\hline & & After & 2.00 & 0.55 & 0.55 & 0.54 & 1.19 & 0.61 \\
\hline \multirow[t]{2}{*}{5} & \multirow[t]{2}{*}{ Singkoyo } & Before & 2.00 & 2.21 & 2.21 & 1.00 & 1.50 & 1.00 \\
\hline & & After & 2.00 & 0.91 & 0.91 & 0.56 & 1.21 & 0.61 \\
\hline \multirow[t]{2}{*}{6} & \multirow[t]{2}{*}{ Tambun } & Before & 2.00 & 1.10 & 1.10 & 1.00 & 1.50 & 1.00 \\
\hline & & After & 2.00 & 0.48 & 0.48 & 0.56 & 1.17 & 0.48 \\
\hline \multirow[t]{2}{*}{7} & \multirow[t]{2}{*}{ Malino } & Before & 2.00 & 1.73 & 1.73 & 1.00 & 1.50 & 1.00 \\
\hline & & After & 2.00 & 0.49 & 0.49 & 0.53 & 1.15 & 0.44 \\
\hline \multirow[t]{2}{*}{8} & \multirow[t]{2}{*}{ Bunta } & Before & 2.00 & 0.16 & 0.16 & 1.00 & 1.50 & 1.00 \\
\hline & & After & 2.00 & 0.13 & 0.13 & 0.54 & 1.18 & 0.50 \\
\hline
\end{tabular}

Based on optimization result as stated in Table VI, Table VII, Table VIII, and Table IX, the deviation of Snyder SUH Model decreased constantly with the increase of E coefficient. The average increase of $\mathrm{E}$ coefficient reached $39.1 \%$, in the range of 0.97 to 0.98 . In Nakayasu SUH Model, the deviation decrease only took place at peak discharge parameter with the increase of E coefficient. E coefficient increased well $31.1 \%$ average with around 0.87 to 0.99 . It differed with Nakayasu SUH Model, the deviation of peak discharge parameter precisely increased with the increase of E. After optimization, E coefficient became 0.68 to 0.82 . It was relatively unsatisfactory yet even though the average increase reached $69.1 \%$. E coefficient increase on GAMA I SUH Model was obtained very well (average 32.8\%) in the range of 0.92 to 0.99 . The increase of E coefficient was also accompanied by the decrease of peak discharge deviation significantly. The deviation change and the increase of E coefficient on ABG SUH Model were similar with that of GAMA I SUH Model with a good significant level. This change did not occur on peak time parameter and base time hydrograph. On ITB-1 SUH Model, the decrease of deviation was relatively consistent with the increase of E coefficient though peak discharge parameter did not decrease in some watersheds such as in Tambun and Malino watersheds.

As shown in Table IX, almost all models revealed the increase of Nash-Sutcliffe Model Efficiency Coefficient (E) with a satisfactory result approached to 1 . The optimization result took place not only due to the increase of Nash-Sutcliffe Model Efficiency Coefficient (E), but also hoped the decrease of peak discharge deviation, peak time, and base time. However, not all parameter deviations decreased (negative value), some had positive values meaning that a bigger deviation happened after optimization. This arose because the process of parameter optimization happened simultaneously, and only based on purpose function by maximizing the Nash-Sutcliffe Model Efficiency Coefficient (E). The adjustment on this coefficient resulted in the increase or the decrease of deviation of SUH Model parameter relying upon the optimum value of E reached in the optimization process. However, as a whole, it could be stated that the deviation decrease of SUH Model parameter was accompanied by the increase of E coefficient (Table VI, Table VII, Table VIII and Table IX).

The decrease of SUH model parameter deviation and the increase of E coefficient showed that optimization used solver facility were very effectively executed. The important thing needed to be observed was that required parameter limits in each SUH model could be invalid as n value in Snyder SUH Model with the limit of 0.2 to 0.3 , based on optimization result the optimum value could be achieved out of these limits. This case indicated that the parameter limits were able to be evaluated.

TABLE VI. Performance improvement of 6 based on QP parameter at 8 watersheds

\begin{tabular}{|c|c|c|c|c|c|c|c|c|}
\hline \multirow{2}{*}{ No. } & \multirow{2}{*}{ Watersheds } & \multirow{2}{*}{ QP } & \multicolumn{6}{|c|}{ Deviation $(\%)$} \\
\hline & & & Snyder & Nakayasu & SCS & GAMA I & $\mathrm{ABG}$ & ITB-1 \\
\hline \multirow[t]{3}{*}{1} & \multirow[t]{3}{*}{ Bahomoleo } & Before & 47.6 & 31.1 & 12.2 & 19.6 & 26.6 & 21.1 \\
\hline & & After & 12.0 & 10.3 & 6.1 & 0.6 & 9.3 & 17.8 \\
\hline & & Changes (\%) & -74.8 & -66.8 & -50.1 & -96.8 & -65.2 & -15.5 \\
\hline \multirow[t]{3}{*}{2} & \multirow[t]{3}{*}{ Pinamula } & Before & 44.8 & 36.7 & 33.1 & 10.8 & 32.0 & 19.3 \\
\hline & & After & 6.5 & 6.4 & 14.0 & 1.0 & 11.8 & 13.1 \\
\hline & & Changes (\%) & -85.4 & -82.6 & -57.6 & -90.5 & -63.2 & -32.0 \\
\hline \multirow[t]{2}{*}{3} & \multirow[t]{2}{*}{ Toaya } & Before & 40.4 & 44.7 & 15.1 & 18.6 & 17.2 & 21.7 \\
\hline & & After & 12.3 & 3.5 & 6.5 & 5.9 & 17.8 & 16.0 \\
\hline
\end{tabular}




\begin{tabular}{|c|c|c|c|c|c|c|c|c|}
\hline \multirow{2}{*}{ No. } & \multirow{2}{*}{ Watersheds } & \multirow{2}{*}{ QP } & \multicolumn{6}{|c|}{ Deviation $(\%)$} \\
\hline & & & Snyder & Nakayasu & SCS & GAMA I & $\mathrm{ABG}$ & ITB-1 \\
\hline & & Changes (\%) & -69.6 & -92.1 & -56.6 & -68.2 & 3.3 & -26.5 \\
\hline \multirow[t]{3}{*}{4} & \multirow[t]{3}{*}{ Bangga } & Before & 42.1 & 38.0 & 2.4 & 20.6 & 35.7 & 15.2 \\
\hline & & After & 10.2 & 3.1 & 23.5 & 2.1 & 12.7 & 13.7 \\
\hline & & Changes (\%) & -75.8 & -91.8 & 861.8 & -90.0 & -64.3 & -10.2 \\
\hline \multirow[t]{3}{*}{5} & \multirow[t]{3}{*}{ Singkoyo } & Before & 30.7 & 50.0 & 21.4 & 25.9 & 35.8 & 16.4 \\
\hline & & After & 8.6 & 9.1 & 15.1 & 0.4 & 15.2 & 11.1 \\
\hline & & Changes $(\%)$ & -71.8 & -81.8 & -29.5 & -98.7 & -57.5 & -32.4 \\
\hline \multirow[t]{3}{*}{6} & \multirow[t]{3}{*}{ Tambun } & Before & 35.3 & 46.2 & 12.8 & 44.0 & 46.5 & 9.5 \\
\hline & & After & 10.5 & 6.8 & 22.6 & 3.8 & 13.8 & 13.0 \\
\hline & & Changes $(\%)$ & -70.3 & -85.2 & 76.2 & -91.4 & -70.4 & 35.9 \\
\hline \multirow[t]{3}{*}{7} & \multirow[t]{3}{*}{ Malino } & Before & 33.3 & 45.2 & 23.1 & 34.1 & 81.2 & 7.0 \\
\hline & & After & 10.6 & 5.8 & 27.5 & 2.0 & 12.5 & 13.1 \\
\hline & & Changes $(\%)$ & -68.1 & -87.1 & 19.0 & -94.2 & -84.6 & 88.8 \\
\hline \multirow[t]{3}{*}{8} & \multirow[t]{3}{*}{ Bunta } & Before & 25.2 & 50.3 & 8.5 & 39.0 & 1.0 & 14.2 \\
\hline & & After & 9.6 & 7.8 & 6.9 & 5.5 & 14.5 & 12.6 \\
\hline & & Changes $(\%)$ & -61.8 & -84.5 & -19.0 & -85.9 & 1326.2 & -11.0 \\
\hline \multicolumn{3}{|c|}{ Average changes $(\%)$} & -72.2 & -84.0 & 93.0 & -89.4 & 115.5 & -0.4 \\
\hline
\end{tabular}

TABLE VII. Performance improvement of 6 based on TP parameter at 8 watersheds

\begin{tabular}{|c|c|c|c|c|c|c|c|c|}
\hline \multirow{2}{*}{ No. } & \multirow{2}{*}{ Watersheds } & \multirow{2}{*}{$\mathrm{TP}$} & \multicolumn{6}{|c|}{ Deviation (\%) } \\
\hline & & & Snyder & Nakayasu & SCS & GAMA I & $\mathrm{ABG}$ & ITB-1 \\
\hline \multirow[t]{3}{*}{1} & \multirow[t]{3}{*}{ Bahomoleo } & Before & 72.8 & 11.5 & 106.6 & 32.6 & 22.4 & 144.0 \\
\hline & & After & 3.5 & 11.5 & 61.1 & 32.6 & 22.4 & 5.7 \\
\hline & & Changes (\%) & -95.2 & 0.0 & -42.6 & 0.0 & 0.0 & -96.1 \\
\hline \multirow[t]{3}{*}{2} & \multirow[t]{3}{*}{ Pinamula } & Before & 42.3 & 12.9 & 150.9 & 17.5 & 25.7 & 101.3 \\
\hline & & After & 1.8 & 12.9 & 33.9 & 17.5 & 25.7 & 5.7 \\
\hline & & Changes (\%) & -95.7 & 0.0 & -77.5 & 0.0 & 0.0 & -94.3 \\
\hline \multirow[t]{3}{*}{3} & \multirow[t]{3}{*}{ Toaya } & Before & 23.7 & 13.0 & 86.8 & 8.1 & 40.0 & 92.7 \\
\hline & & After & 11.0 & 13.0 & 65.7 & 8.1 & 40.0 & 17.1 \\
\hline & & Changes (\%) & -53.7 & 0.0 & -24.3 & 0.0 & 0.0 & -81.5 \\
\hline \multirow[t]{3}{*}{4} & \multirow[t]{3}{*}{ Bangga } & Before & 42.4 & 12.9 & 64.1 & 13.2 & 7.7 & 100.2 \\
\hline & & After & 5.9 & 12.9 & 30.1 & 13.2 & 7.7 & 9.0 \\
\hline & & Changes (\%) & -86.0 & 0.0 & -53.0 & 0.0 & 0.0 & -91.0 \\
\hline \multirow[t]{3}{*}{5} & \multirow[t]{3}{*}{ Singkoyo } & Before & 9.7 & 13.1 & 117.6 & 16.6 & 33.8 & 85.5 \\
\hline & & After & 0.8 & 13.1 & 37.5 & 16.6 & 33.8 & 4.8 \\
\hline & & Changes (\%) & -92.2 & 0.0 & -68.1 & 0.0 & 0.0 & -94.4 \\
\hline \multirow[t]{3}{*}{6} & \multirow[t]{3}{*}{ Tambun } & Before & 33.5 & 13.0 & 56.9 & 29.6 & 10.7 & 95.2 \\
\hline & & After & 5.6 & 13.0 & 42.1 & 29.6 & 10.7 & 8.7 \\
\hline & & Changes (\%) & -83.2 & 0.0 & -26.1 & 0.0 & 0.0 & -90.9 \\
\hline \multirow[t]{3}{*}{7} & \multirow[t]{3}{*}{ Malino } & Before & 33.3 & 13.2 & 50.1 & 18.8 & 7.4 & 96.0 \\
\hline & & After & 1.1 & 13.2 & 148.4 & 18.8 & 7.4 & 3.7 \\
\hline & & Changes (\%) & -96.8 & 0.0 & 196.4 & 0.0 & 0.0 & -96.2 \\
\hline \multirow[t]{3}{*}{8} & \multirow[t]{3}{*}{ Bunta } & Before & 3.0 & 12.9 & 86.4 & 44.6 & 78.3 & 83.3 \\
\hline & & After & 5.6 & 12.9 & 75.0 & 44.6 & 78.3 & 0.9 \\
\hline & & Changes (\%) & 84.8 & 0.0 & -13.2 & 0.0 & 0.0 & -98.9 \\
\hline \multicolumn{3}{|c|}{ Average changes $(\%)$} & -64.8 & 0.0 & 0.0 & 0.0 & 0.0 & -92.9 \\
\hline
\end{tabular}


TABLE VIII. Performance improvement of 6 based on TB parameter at 8 watersheds

\begin{tabular}{|c|c|c|c|c|c|c|c|c|}
\hline \multirow{2}{*}{ No. } & \multirow{2}{*}{ Watersheds } & \multirow{2}{*}{ TB } & \multicolumn{6}{|c|}{ Deviation (\%) } \\
\hline & & & Snyder & Nakayasu & SCS & GAMA I & ABG & ITB-1 \\
\hline \multirow[t]{3}{*}{1} & \multirow[t]{3}{*}{ Bahomoleo } & Before & 558.3 & 58.3 & 16.2 & 68.5 & 17.4 & 174.5 \\
\hline & & After & 534.9 & 91.7 & 9.4 & 68.5 & 17.4 & 18.9 \\
\hline & & Changes $(\%)$ & -4.2 & 57.1 & -42.2 & 0.0 & 0.0 & -89.2 \\
\hline \multirow[t]{3}{*}{2} & \multirow[t]{3}{*}{ Pinamula } & Before & 406.0 & 62.5 & 64.7 & 23.8 & 14.9 & 164.3 \\
\hline & & After & 388.7 & 100.0 & 12.1 & 23.8 & 14.9 & 38.8 \\
\hline & & Changes (\%) & -4.3 & 60.0 & -81.3 & 0.0 & 0.0 & -76.4 \\
\hline \multirow[t]{3}{*}{3} & \multirow[t]{3}{*}{ Toaya } & Before & 355.2 & 88.9 & 39.1 & 16.9 & 12.0 & 186.9 \\
\hline & & After & 349.6 & 88.9 & 23.4 & 16.9 & 12.0 & 74.4 \\
\hline & & Changes $(\%)$ & -1.6 & 0.0 & -40.2 & 0.0 & 0.0 & -60.2 \\
\hline \multirow[t]{3}{*}{4} & \multirow[t]{3}{*}{ Bangga } & Before & 408.2 & 87.5 & 11.8 & 24.5 & 2.5 & 172.8 \\
\hline & & After & 393.3 & 87.5 & 11.4 & 24.5 & 2.5 & 48.6 \\
\hline & & Changes $(\%)$ & -3.7 & 0.0 & -3.6 & 0.0 & 0.0 & -71.9 \\
\hline \multirow[t]{3}{*}{5} & \multirow[t]{3}{*}{ Singkoyo } & Before & 216.8 & 15.4 & 31.8 & 16.6 & 15.8 & 124.7 \\
\hline & & After & 213.5 & 23.1 & 16.7 & 16.6 & 15.8 & 26.9 \\
\hline & & Changes $(\%)$ & -1.5 & 50.0 & -47.4 & 0.0 & 0.0 & -78.4 \\
\hline \multirow[t]{3}{*}{6} & \multirow[t]{3}{*}{ Tambun } & Before & 241.9 & 25.0 & 17.9 & 20.4 & 34.0 & 104.2 \\
\hline & & After & 233.1 & 50.0 & 25.7 & 20.4 & 34.0 & 13.7 \\
\hline & & Changes $(\%)$ & -3.6 & 100.0 & 43.3 & 0.0 & 0.0 & -86.9 \\
\hline \multirow[t]{3}{*}{7} & \multirow[t]{3}{*}{ Malino } & Before & 240.7 & 50.0 & 23.7 & 19.6 & 38.0 & 99.2 \\
\hline & & After & 230.8 & 58.3 & 24.8 & 19.6 & 38.0 & 5.4 \\
\hline & & Changes $(\%)$ & -4.1 & 16.7 & 4.5 & 0.0 & 0.0 & -94.5 \\
\hline \multirow[t]{3}{*}{8} & \multirow[t]{3}{*}{ Bunta } & Before & 193.8 & 32.1 & 10.5 & 25.9 & 25.1 & 117.4 \\
\hline & & After & 190.7 & 42.9 & 20.7 & 25.9 & 25.1 & 17.5 \\
\hline & & Changes $(\%)$ & -1.6 & 33.3 & 97.0 & 0.0 & 0.0 & -85.1 \\
\hline \multicolumn{3}{|c|}{ Average changes $(\%)$} & -3.1 & 39.6 & -8.7 & 0.0 & 0.0 & -80.3 \\
\hline
\end{tabular}

TABLE IX. Performance improvement of 6 based on E coefficient at 8 watersheds

\begin{tabular}{|c|c|c|c|c|c|c|c|c|}
\hline \multirow[b]{2}{*}{ No. } & \multirow[b]{2}{*}{ Watersheds } & \multirow{2}{*}{$\begin{array}{c}\text { The efficiency } \\
\text { coefficient of } \\
\text { Nash-Sutcliffe } \\
\text { Model (E) }\end{array}$} & \multicolumn{6}{|c|}{ Synthetic Unit Hydrograph (SUH) } \\
\hline & & & Snyder & Nakayasu & SCS & GAMA I & $\mathrm{ABG}$ & ITB-1 \\
\hline \multirow[t]{3}{*}{1} & \multirow[t]{3}{*}{ Bahomoleo } & Before & 0.62 & 0.83 & 0.56 & 0.86 & 0.78 & 0.17 \\
\hline & & After & 0.98 & 0.87 & 0.77 & 0.92 & 0.99 & 0.91 \\
\hline & & Changes (\%) & 57.6 & 4.4 & 36.2 & 6.3 & 27.0 & 442.4 \\
\hline \multirow[t]{3}{*}{2} & \multirow[t]{3}{*}{ Pinamula } & Before & 0.59 & 0.77 & 0.23 & 0.88 & 0.65 & 0.35 \\
\hline & & After & 0.98 & 0.96 & 0.82 & 0.99 & 0.94 & 0.93 \\
\hline & & Changes (\%) & 66.1 & 24.9 & 254.0 & 12.7 & 44.2 & 167.9 \\
\hline \multirow[t]{3}{*}{3} & \multirow[t]{3}{*}{ Toaya } & Before & 0.70 & 0.70 & 0.61 & 0.77 & 0.69 & 0.45 \\
\hline & & After & 0.97 & 0.99 & 0.78 & 0.97 & 0.90 & 0.92 \\
\hline & & Changes (\%) & 38.7 & 41.1 & 27.3 & 25.4 & 30.6 & 104.0 \\
\hline \multirow[t]{3}{*}{4} & \multirow[t]{3}{*}{ Bangga } & Before & 0.63 & 0.74 & 0.72 & 0.82 & 0.60 & 0.36 \\
\hline & & After & 0.97 & 0.97 & 0.75 & 0.99 & 0.95 & 0.93 \\
\hline & & Changes (\%) & 54.4 & 32.1 & 3.8 & 21.0 & 57.3 & 155.3 \\
\hline \multirow[t]{3}{*}{5} & \multirow[t]{3}{*}{ Singkoyo } & Before & 0.79 & 0.71 & 0.30 & 0.78 & 0.52 & 0.42 \\
\hline & & After & 0.98 & 0.97 & 0.77 & 0.98 & 0.89 & 0.94 \\
\hline & & Changes (\%) & 24.3 & 35.8 & 157.6 & 24.6 & 73.2 & 125.7 \\
\hline 6 & Tambun & Before & 0.78 & 0.74 & 0.68 & 0.58 & 0.43 & 0.42 \\
\hline
\end{tabular}




\begin{tabular}{|c|c|c|c|c|c|c|c|c|}
\hline \multirow[b]{2}{*}{ No. } & \multirow[b]{2}{*}{ Watersheds } & \multirow{2}{*}{$\begin{array}{c}\text { The efficiency } \\
\text { coefficient of } \\
\text { Nash-Sutcliffe } \\
\text { Model (E) }\end{array}$} & \multicolumn{6}{|c|}{ Synthetic Unit Hydrograph (SUH) } \\
\hline & & & Snyder & Nakayasu & SCS & GAMA I & $\mathrm{ABG}$ & ITB-1 \\
\hline & & After & 0.97 & 0.99 & 0.70 & 0.97 & 0.94 & 0.93 \\
\hline & & Changes (\%) & 25.2 & 33.4 & 3.1 & 66.3 & 118.6 & 124.1 \\
\hline \multirow[t]{3}{*}{7} & \multirow[t]{3}{*}{ Malino } & Before & 0.74 & 0.72 & 0.60 & 0.72 & -0.12 & 0.38 \\
\hline & & After & 0.98 & 0.97 & 0.68 & 0.99 & 0.96 & 0.94 \\
\hline & & Changes (\%) & 31.6 & 35.3 & 13.3 & 38.4 & 919.9 & 150.8 \\
\hline \multirow[t]{3}{*}{8} & \multirow[t]{3}{*}{ Bunta } & Before & 0.85 & 0.67 & 0.47 & 0.55 & 0.68 & 0.40 \\
\hline & & After & 0.98 & 0.95 & 0.75 & 0.92 & 0.70 & 0.95 \\
\hline & & Changes (\%) & 15.3 & 41.4 & 57.7 & 68.0 & 2.6 & 139.9 \\
\hline \multicolumn{3}{|c|}{ Average changes(\%) } & 39.1 & 31.1 & 69.1 & 32.8 & 159.2 & 176.3 \\
\hline
\end{tabular}

\section{CONCLUSION}

The performance improvement of 8 SUH models using solver facility of Microsoft Excel could decrease the parameter deviation of SUH model for peak discharge parameter and an average peak time up to below $30 \%$ and could increase the Nash-Sutcliffe Model Efficiency Coefficient (E) up to over $80 \%$. The occurrence of the decrease of SUH model parameter deviation and the increase of E coefficient unveiled that optimization using solver facility was very effective to be conducted. However, not all these parameter deviations decreased as some of them increased significantly after optimization. It took place due to the simultaneous parameter optimization process and only based on the purpose function by maximizing the Nash-Sutcliffe Model Efficiency Coefficient (E). The adjustment on this coefficient resulted in the increase or decrease of SUH Model parameter deviation depending on the optimum of $E$ value achieved in the optimization process. However, in general, could be stated that the decrease of SUH model parameter deviation was accompanied by maximizing the Nash-Sutcliffe Model Efficiency Coefficient (E). SUH model coefficient which was evaluated particularly with non-associated coefficient with watershed physical meaning, such as watershed storage coefficient $\left(\mathrm{C}_{t}\right)$, empirical constants $\left(\mathrm{C}_{\mathrm{p}}\right)$ and constants (n) on SUH Snyder and other parameters of other SUH models, could be obtained beyond the fixed limit to get optimum model performances. This case disclosed that the fixed coefficient limits were not attached to but relied upon the evaluated watershed behaviour. Therefore, to obtain valid parameter limits for various watersheds a test on other watersheds with various characteristics needed to be executed.

\section{ACKNOWLEDGMENT}

This article is part of doctoral research in Civil Engineering Department, Institut Teknologi Sepuluh Nopember (ITS) Surabaya. Author thanks to Ministry of Research, Technology and Higher Education which supports with BPPDN Scholarship.

\section{REFERENCES}

[1] Indonesian Geospatial Information Agency, Indonesian Topography Map,Jakarta, 1999. [in Indonesian)

[2] I.G. Tunas, N. Anwar, and U. Lasminto, "Fractal characteristic analysis of watershed as variable of synthetic unit hydrograph model", The Open Civil Engineering Journal., vol. 10, pp. 706-718, Sep. 2016.

[3] A.B. Safarina, H.T. Salim, I.K. Hadihardaja, and M. Syahril, "Clusterization of synthetic unit hydrograph methods based on watershed characteristics", International Journal of Civil \& Environmental Engineering, vol. 11, pp. -, 2011

[4] A.B. Safarina, "Modified Nakayasu Synthetic Unit Hydrograph Method for meso scale ungauge watersheds", International Journal of Engineering Research and Applications, vol. 2, pp. 649-654, 2012

[5] K. Pareta, and U. Pareta, "Quantitative geomorphological analysis of a watershed of Ravi River Basin, H.P. India", International Journal of Remote Sensing and GIS, vol. 1, pp. 41-56, 2012

[6] A.W. Salami, S.O. Bilewu, A.M. Ayanshola, and S.F. Oritola, "Evaluation of synthetic unit hydrograph methods for the development of design storm hydrographs for rivers in South-West, Nigeria", Journal of American Science, vol. 5 no. 4, pp. 23-32, 2009.

[7] C.D. Soemarto, Engineering Hydrology, Erlangga, Jakarta, 1985 [in Indonesian)

[8] R. Viji, P.R. Prasanna, and R. Ilangovan, "Modified SCS-CN and Green-Ampt Methods in surface runoff modelling for the Kundahpallam Watershed, Nilgiris, Western Ghats, India", Aquatic Procedia-International Conference on Water Resources, Coastal and Ocean Engineering, vol. 4, pp. 677-684, 2015

[9] Sri Harto, GAMA I Synthetic Unit Hydrograph, Publisher of Indonesian Public Work Ministry, Jakarta, 1985 [in Indonesian)

[10] Lasidi, Edijatno, and N. Anwar, "Synthetic unit hydrograph of $\alpha \beta \gamma$ ", Proceeding of National Seminar PIT XX HATHI, 20-21 October, 2003 [in Indonesian)

[11] D.K. Natakusimah, W. Hatmoko, and D. Harlan, "General procedure calculation of synthetic unit hydrograph using ITB method and its application examples", Journal of Teknik Sipil, vol. 18 no. 3, pp. 251-291, 2011 [in Indonesian)

[12] C. Cheng, S. Cheng, J. Wen, and J. Lee, "Time and flow characteristics of component hydrographs related to rainfall-stream flow observations", Journal of Hydrologic Engineering, vol. 18 no. 6, pp. 675-688, 2013

[13] K. Subramanya, Engineering Hydrology, McGraw Hill, New Delhi, 1995

[14] L. Montarcih, "The limiting physical parameters of synthetic unit hydrograph", World Applied Sciences Journal, vol. 7 no. 6, pp. $802-$ 804,2009 


\section{AUTHOR PROFILE}

I Gede Tunas, as a lecturer in the Faculty of Civil Engineering Department, University of Tadulako-Indonesia and as a researcher in the field of water resources engineering and management since 2000, graduating in Civil Engineering of Tadulako University (1999), Master of Civil Engineering in 2004 at the Gadjah Mada UniversityYogyakarta Indonesia and Ph.D Students in Civil Engineering at the Institut Teknologi Sepuluh Nopember (ITS) Surabaya-Indonesia (2014-now).

Nadjadji Anwar, as a professor and researcher in Civil Engineering in the field of water resources engineering and management at the Institut Teknologi Sepuluh Nopember (ITS) Surabaya-Indonesia. He received Bachelor's degree in Civil Engineering from Institut Teknologi Bandung (ITB), Bandung, Indonesia in 1979, Master of Science in Civil Engineering, Colorado State University, Fort Collins, Colorado, USA in 1982 and Doctor of Engineering in Civil and Environmental Engineering, Toyo University, Kawagoe-Shi, Saitama, Japan in 1998.

Umboro Lasminto, as a senior lecturer and researcher in Civil Engineering in the field of water resources engineering and management at the Institut Teknologi Sepuluh Nopember (ITS) Surabaya-Indonesia. He obtained Bachelor's degree in Civil Engineering from Institut Teknologi Sepuluh Nopember (ITS) Surabaya (1996), Master of Science (M.Sc.) in Hydroinformatic (2004), and Doctor in Hydraulic Engineering and Water Resources from Technische Universität Graz, Austria (2012). 